\title{
The Laying Hen Productivity Comparison between Automatic and Manual Feeding System in Malang, Indonesia
}

\author{
N. Febrianto, B. Hartono, H. D. Utami, B. A. Nugroho
}

\begin{abstract}
This research aims to analyze the egg productivity and profitability between laying hen farms fed with automatic and manual feeding system. The research is conducted in 5 closed-house for each feeding system, and each house consisted of 20,000 laying hens. The egg productivity was determined by measuring the feed conversion ratio $(F C R)$, hen day production (HDP) and hen house production (HHP), while the profitability was measured by measuring the farming profit/loss ratio. All of the data were then analyzed with SPSS Direct Marketing. The results showed that manual feeding system had $65 \%$ profit/loss ratio, while the automatic feeding had $67 \%$. Moreover, the automatic feeding showed better egg productivity with FCR at 2.05 , HDP at $87.04 \%$, and HHP at $22.6 \mathrm{~kg}$, while the manual feeding showed FCR at 2.23, HDP at $82.05 \%$, and HHP at 21.4 $\mathrm{kg}$. It concludes that the utilization of automatic feeding system had better egg productivity as seen by the FCR, HDP, and HHP, and thus resulted in higher profitability.
\end{abstract}

Keywords: Egg productivity, Feeding machine, Laying hen.

\section{INTRODUCTION}

The development of animal production sector has been a part of national agricultural development and became an integral part for national development. The development of animal production aims to fulfils the national demand for food and nutrients. Research by Arifin [1] showed that the animal production should be developed by following the modern agribusiness model with end to end production management. The laying hen farming industry is one of various animal production industries which has been expected to grow further to achieve multifunctional profitability aside from fulfilling the national demand. It is also noting that the national population has been increasing along with the awareness to consume healthy and nutritional food.

Chicken egg has been widely known as animal-based protein which provides various benefits to the human health. The product has also widely preferred and used in many dishes. The laying hen farm, which by its nature able to produce chicken egg and meat, thus held a potential to be developed whether in small to industrial scale. Malang regency is one of the regencies located in East Java,

Revised Manuscript Received on January 5, 2020.

* Correspondence Author

Nanang Febrianto*, Department of Social and Economic, Universitas Brawijaya, Malang, Indonesia. Email: nanangfeb@ub.ac.id

Budi Hartono, Department of Social and Economic, Universitas Brawijaya, Malang, Indonesia.

Hari Dwi Utami, Department of Social and Economic, Universitas Brawijaya, Malang, Indonesia.

Bambang Ali Nugroho, Department of Social and Economic, Universitas Brawijaya, Malang, Indonesia.
Indonesia. The regency has various supporting factors for animal farming industry, such as abundant feed sources, animal breeds, and human resources. This condition thus turns farming industries, especially laying hen, as the featured commodities in the regency. The data from the Department of Animal Husbandry [2] in Malang Regency showed that there are about 43 millions of hens are reared in the regency, and has been continuously increasing since the last three years. In terms of egg production, the Indonesian Statistics [3] has recorded that 42 thousand tons of chicken egg were produced in 2015 .

The closed house farming system has been widely used in laying hen farm in Malang regency. The system provides a controlled environment to support the egg production. Moreover, the closed house system would prevent the hen to be exposed to extreme environment, minimize disease agent transmission from the environment, provide suitable temperature and humidity for the hen, as well as facilitate easier maintenance and harvest for the farmers. However, even though the system offers various benefits, it is still very expensive to apply. The system requires high capitals to buy all of the farming equipment as for the early investment. A decent economic analysis is then required to ensure the farming profitability and sustainability. In this study, we conduct the productivity and profitability analysis in laying hen farm which used automatic and manual feeding system. The results of this research are then expected to elucidate laying hen farmers on the utilization of automatic and manual laying hen feeding system in regards to the produced profits, and also provide them with reference to decide which would be the most suitable system.

\section{MATERIALS AND METHODS}

The research was conducted in Bella Jaya Group PS farm located in Malang Regency, East Java, Indonesia. As much as 10 closed house laying hen farms were divided into two groups, with each group consisted of 5 closed house farms and each farm reared around 20,000 laying hens at the age of 30 weeks (production period). In the first group, the laying hen were fed with automatic feeding system, while in the other group the feeding was done by using manual feeding system. In the automatic feeding system, a sensor was placed to detect and determine the amount and feeding time; while in the manual feeding system, the feed was given according to the scheduled time. 
This research used two variables correlation approach, and a survey with purposive sampling was conducted to determine the correlation among research variables. The feed conversion ratio (FCR), hen day production (HDP) and hen house production (HHP) data were collected to determine the egg production, while a quantitative analysis was performed to measure the profit. All of the data were obtained in one laying period (55 weeks) from February 2017 to April 2018, and the results are analyzed descriptively.

\section{RESULTS AND DISCUSSION}

The egg productivity between chicken fed with manual and automatic feeding system is provided in Table- I.

Table- I. The FCR, HDP, and HHP of laying hen fed with automatic and manual feeding system

\begin{tabular}{|c|c|c|c|}
\hline Feeding System & FCR & HDP (\%) & HHP (kg) \\
\hline Manual & 2.23 & 82.06 & 21.3 \\
\hline Automatic & 2.05 & 87.05 & 22.6 \\
\hline \multicolumn{4}{|c|}{ Note: The egg production was measured in one laying period }
\end{tabular}

In Table 1, the FCR of laying chicken fed with automatic feeding system was lower $(\mathrm{FCR}=2.05)$ compared to the manual $(F C R=2.23)$. This showed that automatic feeding system had better feeding efficiency compared to the manual feeding system. Gerzilov [4] stated that FCR indicates the conversion ratio of the total amount of consumed feed to the amount of production, thus a farm with lower FCR indicates a more efficient production. The higher FCR found in the manual feeding system was due to the higher stress experienced by the laying hens during the feeding. The activity of the human labours during feeding could threaten the chicken, thus initiate stressful condition. Research by Gunawan and Sihombing [5] showed that the stress condition of laying hens could reduce its egg productivity. Other stress inducing factors in laying hens include high density and extreme temperature. Moreover, the automatic feeding system would suppress feed waste as the feeding would be determined by the machine sensor [6]

The HDP in the automatic feeding system was $87.04 \%$, higher than the manual feeding which reached $82.05 \%$ HDP. The measurement of HDP could be used to determine the laying hen farming efficiency. Gerzilov [4] showed that higher HDP indicates a more efficient egg production and has positive correlation with FCR. The HHP is amount of produced eggs in a certain period of time. In Table- I, it can be seen that the utilization of automatic feeding system would produce higher HHP compared to the manual feeding. In this research, it is shown that the usage of automatic feeding system could save around 2 to 3 grams of feed for each chicken daily due to less feed waste.

The production cost of laying hen farming in this study is presented in Table- II and III. The production cost is divided into fixed costs which consisted of land, laying hens, housing and equipment, while the variable costs consisted of feed, medicine, vaccine, water, and electricity. In Table- II and III, it can be seen that the feed cost in automatic feeding system was higher compared to the manual, even though in the FCR observation, the utilization of automatic feeding system could suppress feed waste and improve production efficiency. This condition was due to the higher feed intake was found in the automatic feeding system, which will support the egg production of the hen.

Table- II. Production cost of the manual fed laying hen farming

\begin{tabular}{|l|r|}
\hline Production Cost & Price (IDR) \\
\hline Fixed Cost & $125,700,500$ \\
\hline Land & $341,300,500$ \\
\hline Laying hens & $233,500,500$ \\
\hline Housing & $269,500,500$ \\
\hline Equipment \\
\hline Variable Cost & $1,567,756,550$ \\
\hline Feed & $17,754,250$ \\
\hline Medicine and vaccine & $29,989,550$ \\
\hline Water and electricity & $\mathbf{2 , 5 7 2 , 9 9 9 , 7 5 0}$ \\
\hline Total production cost & laying period \\
\multicolumn{2}{|c|}{ Note: IDR = Indonesian Rupiah; the production cost was measured in one }
\end{tabular}

Table- III. Production cost of the automatic fed laying hen farming

\begin{tabular}{|l|c|}
\hline Production Cost & Price (IDR) \\
\hline Fixed Cost & $128,050,500$ \\
\hline Land & $411,700,500$ \\
\hline Laying hens & $281,500,500$ \\
\hline Housing & $374,500,500$ \\
\hline Equipment \\
\hline Variable Cost & $1,802,908,550$ \\
\hline Feed & $25,880,750$ \\
\hline Medicine and vaccine & $33,190,550$ \\
\hline Water and electricity & $\mathbf{3 , 0 5 7 , 7 3 1 , 8 5 0}$ \\
\hline Total production cost & Note: IDR = Indonesian Rupiah; the production cost was measured in one
\end{tabular}

laying period

Research by Maspique dan Sawe[7] showed that the ideal feed cost would cover around 60 to $80 \%$ of total production cost. According to the total production in Table- II and III, the utilization of automatic feeding system requires higher cost compared to the manual feeding. The result is expected as the usage of automatic feeding system would require higher equipment cost and added with higher feed intake of the hen as well. In order to further understand the profitability, we calculate the generated income and profit/loss ratio analysis as presented in Table- IV and V.

Table- IV. Generated Income between Manual and Automatic Feeding System

\begin{tabular}{|c|c|c|}
\hline Products & $\begin{array}{c}\text { Manual feeding } \\
\text { (IDR) }\end{array}$ & $\begin{array}{c}\text { Automatic feeding } \\
\text { (IDR) }\end{array}$ \\
\hline Eggs & 6.940 .430 .500 & 8.780 .840 .500 \\
\hline Meat & 322.280 .250 & 341.165 .250 \\
\hline Total & 7.262 .710 .750 & 9.122 .005 .750 \\
\hline
\end{tabular}

Note: IDR = Indonesian Rupiah; the production cost was measured in one laying period

Table- V. Profit/Loss Ratio between Manual and

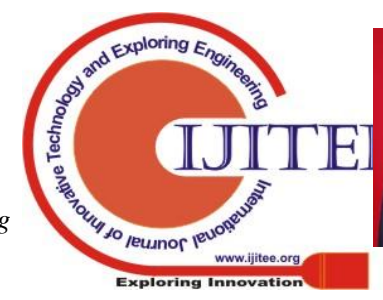




\section{Automatic Feeding System}

\begin{tabular}{|c|c|}
\hline Feeding system & Profit/Loss Ratio \\
\hline Automatic & $67 \%$ \\
\hline Manual & $65 \%$ \\
\hline
\end{tabular}

The profit/loss ratio on automatic feeding system (67\%) was higher compared to the manual feeding $(65 \%)$ even though the automatic feeding system had higher production cost. This showed that even though the automatic feeding system could generate higher income and profitability. The profit/loss ratio analysis is aimed to determine the ratio of profit in the unit of percentage, and provide a simpler calculation to decide the business profitability. In this study, the higher profit/loss ratio in automatic feeding system showed that the system would provide more profit to the farmer compared to the manual feeding. Hansen and Mowen [8] stated that the profit/loss ratio analysis should be presented in the financial report so that the effect of different systems applied in the business model could be determined.

\section{CONCLUSION}

The automatic feeding system showed better egg productivity and had higher profit/loss ratio compared to the manual in the closed house hen laying farm. The results suggest to the utilization of automatic feeding system to improve the laying hen farming profitability.

\section{REFERENCES}

1. A. Bustanu,

"Agribisnisberbasispeternakan," in ArtikelPeluangInvestasi. Bogor: InstitutPertanian Bogor, 2009. (In Indonesian)

2. Department of Animal Husbandry, StatistikPeternakan dan KesehatanHewan 2015. Malang: Ditjennak, 2016. (In Indonesian)

3. Indonesian Statistics, Malang dalam Angka 2015. Malang: BPS Kabupaten Malang, 2016. (In Indonesian)

4. V. V. D. Gerzilov, "Effect of poultry housing systems on egg production," in Bulgarian Journal of Agricultural Science, vol. 18, no. 6, pp. 953-957, 2012.

5. Gunawan and D. T. H. Sihombing, Pengaruh SuhuLingkungan Tinggi Terhadap Kondisi dan Produktivitas Ayam Buras. Bogor: InstitutPertanian Bogor, 2004. (In Indonesian)

6. P. Robert, Poultry Housing and Management in Developing Country. Queensland: School of Veterinary Science University of Queensland, 2001

7. P. Maspique and R. E. Sawe, "Marketing strategy analysis of broiler eggs in large scale livestock regency Sidrap".

8. D. R. Hansen and M. M. Mowen, Akuntansi Manajerial. Jakarta: Salemba Empat, 2009. (In Indonesian)

\section{AUTHORS PROFILE}

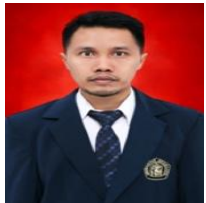

Nanang Febrian, to works in the Department of Social and Economics, Faculty of Animal Science, Universitas Brawijaya. Achieved his doctoral degree in the Universitas Brawijaya, his works has been focused on the micro and small business management and feasibility studies of animal farm.

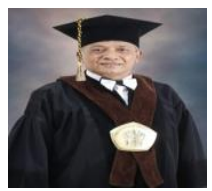

Budi Hartono, is a professor in the Department of Social and Economics, Faculty of Animal Science, Universitas Brawijaya. His research has been focused on the economics of farmer household.
Hari DwiUtami, achieved her $\mathrm{PhD}$ in Agriculture Tropical Management in Massey University, New Zealand. An active researcher and lecturer in the Department of Social and Economic, Faculty of Animal Science, UniversitasBrawijaya. Her research is focused on agribusiness planning and animal product marketing strategy.

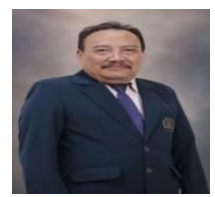

Bambang Ali Nugroho, is an active researcher and lecturer in the Department of Social and Economic, Faculty of Animal Science, UniversitasBrawijaya. His work focused on the dairy development dan small-medium enterprises business development. 